\title{
PEMANFAATAN GOOGLE JAMBOARD DALAM PEMBELAJARAN JARAK JAUH KIMIA MATERI SENYAWA HIDROKARBON
}

\author{
LENY CHRISTIANA
}

SMAN 1 Malinau Kalimantan Utara

e-mail: lenychristiana91@guru.sma.belajar.id

\begin{abstract}
ABSTRAK
Fitur-fitur yang disediakan oleh google secara gratis memang sangat membantu terlaksananya Pembelajaran Jarak Jauh ini. Namun peserta didik menyampaikan keluhannya dimana Bapak/ Ibu guru hanya menjelaskan dengan ceramah dengan menampilkan materi saat pembelajaran menggunakan google meet dan memberikan materi baik berupa modul atau video, serta tugas berupa soal yang jumlahnya variatif, kemudian dikumpulkan melalui google classroom, selanjutnya langsung penilaian harian jika Kompetensi Dasar yang disampaikan sudah selesai. Pada mata pelajaran tertentu mungkin tidak menjadi masalah dengan proses pembelajaran seperti itu. Namun pada kimia yang merupakan mata pelajaran eksakta, tentunya membingungkan, membosankan, dan rawan terjadi miskonsepsi materi pada peserta didik. Berdasarkan kondisi ini, diperlukan media penunjang untuk memperbaiki pembelajaran jarak jauh kimia yang sebelumnya hanya menggunakan google meet sebagai media tatap maya. Penelitian yang dilakukan merupakan penelitian kualitatif dengan menggunakan metode deskriptif di SMAN 1 Malinau Kalimantan Utara kelas XI MIPA 2 Tahun Pelajaran 2021/2022 semester ganjil. Penelitian ini dilaksanakan dalam 2 tahap, yaitu: persiapan dengan berdiskusi dan berkomunikasi melalui Whatsapp Group, dan pelaksanaan Pembelajaran Jarak Jauh kimia dengan memanfaatkan google jamboard sebagai penunjang pertemuan tatap maya google meet. Peserta didik menjadi lebih tertarik dalam mengikuti Pembelajaran Jarak Jauh kimia, karena dengan pemanfaatan media google jamboard ini mendukung model pembelajaran discovery learning dalam menyelesaikan Lembar Kegiatan Peserta Didik (LKPD) sehingga ketika mendiskusikan tahap pengolahan data LKPD, peserta didik terdorong melakukan penemuan secara kolaboratif pada saat pertemuan tatap maya. Pemanfaatan google jamboard dapat digunakan untuk materi kimia lainnya atau mata pelajaran lain yang memerlukan penjelasan bersifat matematis.
\end{abstract}

Kata Kunci: google jamboard, discovery learning, Lembar Kegiatan Pesrta Didik

\section{PENDAHULUAN}

Pembelajaran Jarak Jauh di masa pandemi Covid-19 telah dilalui hampir 1,5 tahun dengan Apabila memanfaatkan aplikasi Google Meet untuk menunjang pembelajaran yang diharapkan efektif. Menurut Pernantah, Nova, \& Ramadhani (2021), aplikasi google meet sebagai alternatif pembelajaran daring menjadi lebih efektif dalam penyampaian materi kepada siswa. Penggunaan google meet pada saat pembelajaran membuat guru lebih leluasa dalam menjelaskan materi sebagaimana hampir mirip dengan situasi pembelajaran tatap muka, pada aplikasi google meet juga guru bisa bertatap muka dengan siswa meskipun secara virtual. Terpenting, google meet dapat diakses secara gratis oleh semua guru dan tidak perlu membeli akun premium seperti aplikasi berbayar lainnya.

Fitur-fitur yang disediakan oleh google secara gratis memang sangat membantu terlaksananya Pembelajaran Jarak Jauh ini. Namun peserta didik menyampaikan keluhannya dimana Bapak/ Ibu guru hanya menjelaskan dengan ceramah dengan menampilkan materi saat pembelajaran menggunakan google meet dan memberikan materi baik berupa modul atau video, serta tugas berupa soal yang jumlahnya variatif, kemudian dikumpulkan melalui google classroom, selanjutnya langsung penilaian harian jika Kompetensi Dasar yang disampaikan sudah selesai. Pada mata pelajaran tertentu mungkin tidak menjadi masalah dengan proses pembelajaran seperti itu. Namun pada mata pelajaran kimia yang merupakan mata pelajaran eksakta, tentunya membingungkan, memosankan, dan rawan terjadi miskonsepsi materi pada 
peserta didik. Ketika kegiatan diskusi berlangsung, ada pertanyaan dari peserta didik, kemudian hanya dijawab oleh teman lainnya ataupun konfirmasi dari pendidik menggunakan kata-kata saja tanpa menampilkan visual berupa tulisan secara langsung (real time) seperti saat belajar di dalam kelas dengan memanfaatkan papan tulis. Akibatnya hanya beberapa yang aktif mengumpulkan tugas di google classroom.

Berdasarkan kondisi ini, diperlukan media penunjang untuk memperbaiki pembelajaran jarak jauh kimia yang sebelumnya hanya menggunakan google meet sebagai media tatap maya. Pembelajaran Jarak Jauh kimia tetap menggunakan pendekatan saintifik dimana peserta didik dibiasakan untuk berfikir menggunakan keterampilan $4 \mathrm{C}$ (critical thinking, creativity, collaborative, and communication) dengan model pembelajaran discovery learning dan Lembar Kegiatan Peserta Didik (LKPD) yang membimbing peserta didik secara mandiri dalam menemukan pemahaman materi yang sedang dipelajarinya. Sesuai implementasi Kurikulum 2013 menurut Permendikbud Nomor 22 Tahun 2016 tentang Standar Proses menggunakan model pembelajaran yang diharapkan dapat membentuk perilaku saintifik, sikap spiritual sosial serta mengembangkan rasa keingintahuan. Salah satunya adalah model pembelajaran melalui penyingkapan/ penemuan (Discovery Learning). Adapun langkah-langkah kerja model pembelajaran Discovery Learning: (1) Pemberian rangsangan (stimulation), (2) Pernyataan/identifikasi masalah (problem statement), (3) Pengumpulan data (data collection), (4) Pengolahan data (data processing), (5) Pembuktian (verification), (6) Menarik simpulan/generalisasi (generalization). Menurut hasil penelitian Izzatunnisa, Andayani, dan Hakim (2019), LKPD berbasis pembelajaran penemuan layak, praktis, dan efektif dalam meningkatkan kemampuan literasi sains peserta didik. Menurut Gideon \& Rahmansyah (2021), Discord dapat digunakan sebagai alternatif PJJ online karena lebih ramah kuota dan semakin baik jika dipadukan aplikasi Google Jamboard dan Powerpoint, dapat mengakomodir mata kuliah Fisika, dan didukung hasil survei, 34 dari 39 mahasiswa ingin menggunakannya untuk mata kuliah yang membutuhkan penjelasan yang bersifat matematis lainnya.

Pemanfaatan media google jamboard dalam pembelajaran jarak jauh kimia membuat pertemuan tatap maya google meet menjadi lebih efektif. Peserta didik dapat berdiskusi dan berkolaborasi dengan saling menampilkan hasil pemahaman mereka saat mengerjakan Lembar Kegiatan Peserta Didik (LKPD), menanggapi pendapat temannya yang dituliskan dengan tangan saat itu juga (bukan menampilkan foto hasil pekerjaannya) menggunakan tools google jamboard. Begitu pula pendidik sebagai fasilitator, jika dirasa perlu memberikan konfirmasi hasil diskusi peserta didik pun dapat menampilan tulisan tangan saat tatap maya berlangsung. Model dan media google jamboard dapat dimanfaatkan dalam mempelajari materi kimia kelas XI pada Kompetensi Dasar 3.1 menganalis struktur dan sifat senyawa hidrokarbon berdasarkan kekhasan atom karbon dan golongan senyawanya, 4.1 membuat model visual berbagai struktur molekul hidrokarbon yang memiliki rumus molekul yang sama (Permendikbud 2018 No. 37).

\section{METODE PENELITIAN}

Penelitian yang dilakukan merupakan penelitian kualitatif dengan menggunakan metode deskriptif. Penelitian kualitatif merupakan jenis penelitian dengan desain yang umum dan fleksibel, sampel yang kecil dan tidak representatif, mementingkan proses, menjadikan peneliti sebagai instrumen penelitian, serta hasilnya berupa penemuan yang tidak dicapai menggunakan statistik (Siyoto \& Sodiq, 2015). Penelitian dilakukan di SMA Negeri 1 Malinau Kalimantan Utara kelas XI MIPA 2 Tahun Pelajaran 2021/2022 semester ganjil. Jumlah peserta didik pada kelas tersebut adalah 31 .

Penelitian ini dilaksanakan dalam 2 tahap, yaitu: (1) persiapan, yaitu berdiskusi dan berkomunikasi dengan peserta didik di kelas XI MIPA 2 melalui Whatsapp Group, membagikan video tutorial google jamboard yang bisa diakses dengan mudah menggunakan Youtube; (2) pelaksanaan Pembelajaran Jarak Jauh kimia, yaitu dengan memanfaatkan google jamboard Senin, 26 Juli 2021. 


\section{HASIL DAN PEMBAHASAN}

\section{Hasil}

Tahap pertama pada penelitian ini adalah persiapan, yaitu dengan melakukan komunikasi dan koordinasi dengan peserta didik XI MIPA 2 melalui Whatsapp Group terkait video tutorial google jamboard yang dapat diakses melalui youtube, tahap ini disajikan pada gambar 1. Tahap ini dilaksanakan sebelum jadwal Pembelajaran Jarak Jauh kimia di hari Sabtu, 24 Juli 2021. Karena di hari Sabtu tidak ada jadwal PJJ, namun diisi dengan kegiatan bimbingan wali kelas, guru mata pelajaran, dan guru BK. Adapun tutorial yang digunakan sebagari referensi diantaranya adalah cara menggunakan Jamboard Google untuk pembelajaran daring (Indah Math, 2021) dan tutorial cara menggunakan jamboard (Langit Merah, 2020).

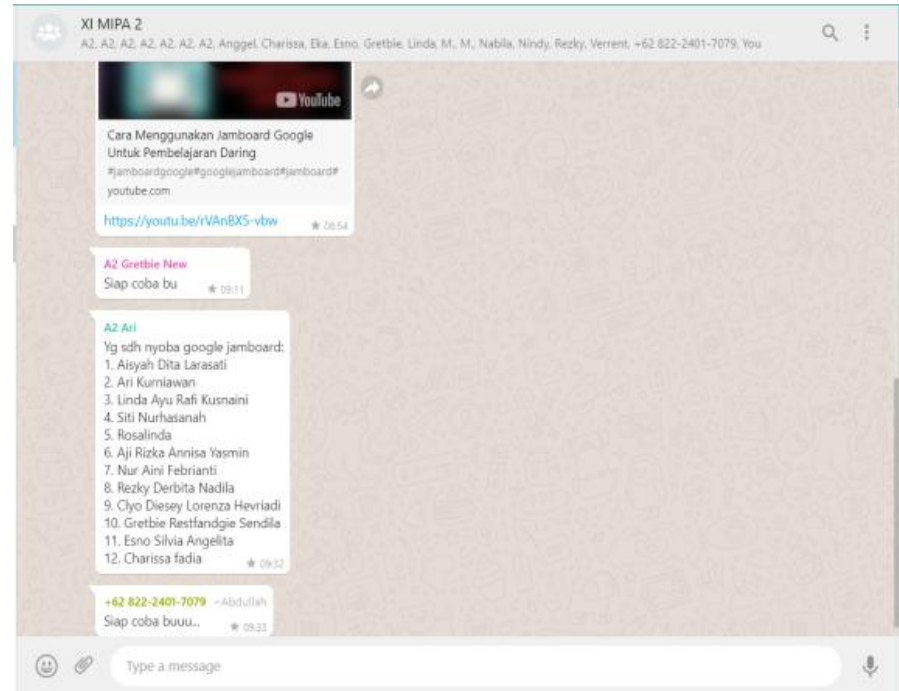

\section{Gambar 1. Koordinasi Tutorial Google Jamboard dengan peserta didik XI MIPA 2.}

Jamboard adalah papan tulis digital dari google yang telah terintegrasi dengan berbagai layanan cloud. Jamboard hadir untuk memudahkan kolaborasi secara real time antara pendidik dengan peserta didik sehingga bisa membuat pembelajaran lebih menarik dan interaktif pada kegiatan tatap maya (Rosidah, 2021). Pendidik dapat mengajak peserta didik untuk membuat sketsa ide, memecahkan masalah atau menggambar secara kolaboratif. Google jamboard ini dapat digunakan sangat mudah baik dari smartphone atau laptop dengan cara masuk akun google masing-masing terlebih dahulu. Jika menggunakan smartphone, cara mengaplikasikannya seperti biasa dengan sentuhan. Google jamboard dibuka menggunakan google chrome dengan mode tampilan desktop supaya seperti tampilan di laptop atau menginstall aplikasi google jamboard dari playstore. Peserta didik dapat memilih mana yang mudah penggunaannya. Ketika menggunakan laptop touchscreen bisa menggunaan sentuhan layar atau menggunakan mouse, pengguna dapat memilih mana yang lebih nyaman, dengan seperti biasa sign in akun google melalui google chrome, dan memilih google jamboard pada google app (titik sembilan di bagian kanan atas) seperti pada gambar 2 berikut ini. 


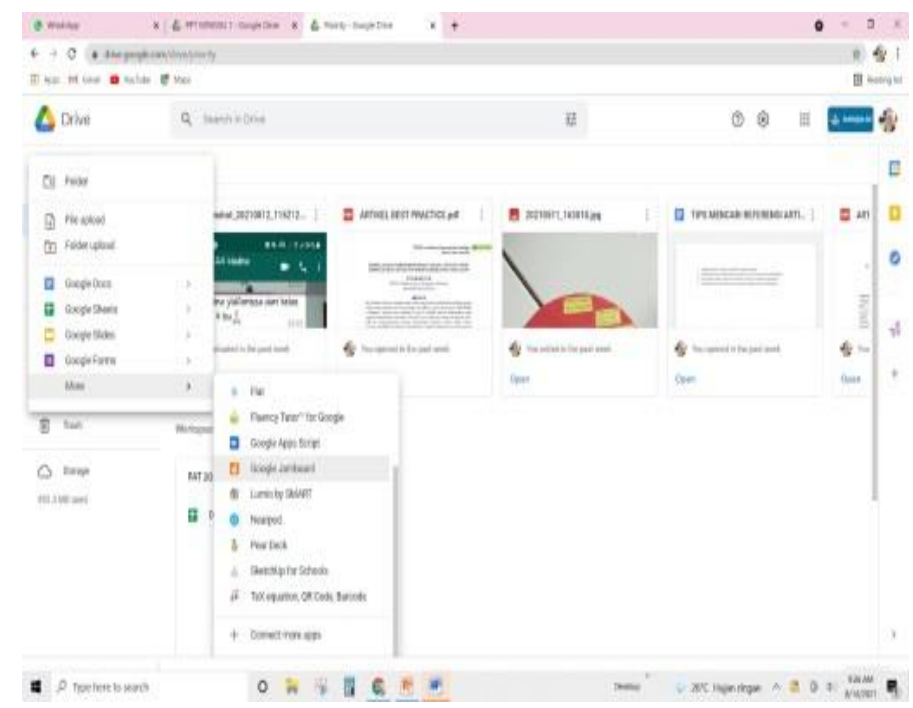

Gambar 2. Cara membuat file jam pada google jamboard.

Kemudian untuk mengisi file jam (frame jam/ slide) tersebut dengan memanfaatkan tools dalam google jamboard ketika proses Pembelajaran Jarak Jauh berlangsung. Adapun tools dan fungsinya adalah sebagai berikut: (1) Pen, fungsinya untuk menulis manual dan ada pilihan ukuran pulpen dan warnanya. Hanya menggunakan tool pen ini aka kesulitan jika menggunakan mouse, lebih mudah menggunakan smartphone atau laptop touchscreen; (2) Erase, untuk menghapus tulisan di papan tulis; (3) Tanda panah, untuk mengembalikan fungsi mouse (4). Sticky Note, untuk membuat note berwarna untuk menandai catatan penting; (5) Add image, untuk menambahkan gambar pada frame jam. Gambar bisa mengambil dari perangkat atau dari mesin pencarian google. Contoh memasukan gambar dengan mencari dari google. Tinggal klik insert maka gambar yang dipilih akan masuk di frame jam; (6) Circle, untuk menambah bentuk benda dengan pilihan yang tersedia; (7) Text Box, untuk menambah teks yang bisa dibuat untuk memberikan penjelasan materi, memberikan pertanyaan, mengajak diskusi peserta didik; (8) Laser, digunakan sebagai pointer untuk menunjukkan materi yang sedang dijelaskan; (9) tombol-tombol tambahan antara lain: set background untuk mengubah warna tampilan frame, clear frame untuk menghapus isian frame secara keseluruhan, dan tombol undo redo. Dalam satu file jam ini, maksimal terdidi dari 20 frame/ slide. Tools pada frame jamboard (file jam) ditampilkan pada gambar 3 .

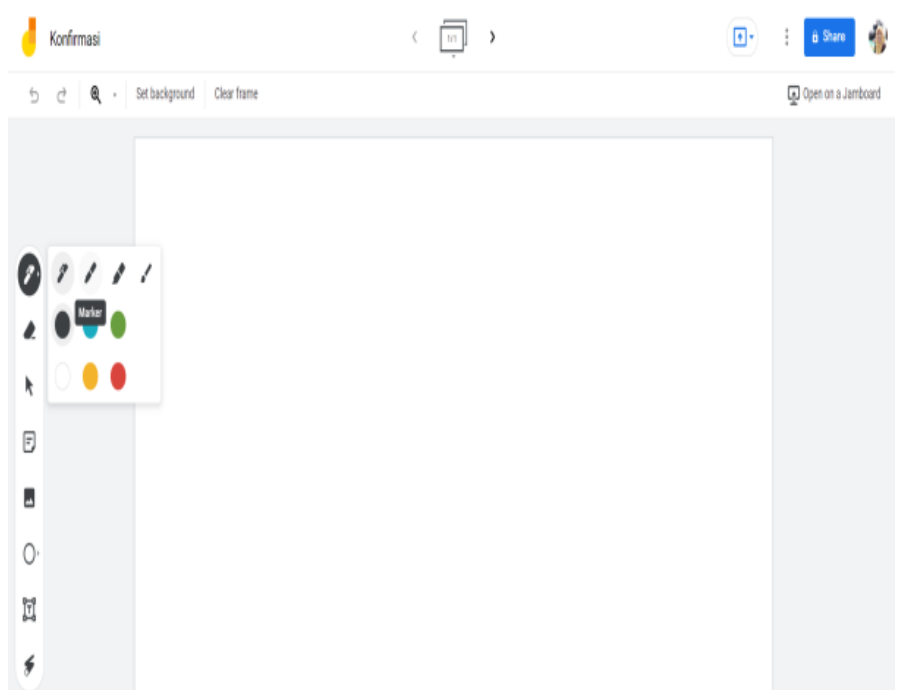

Gambar 3. Tools untuk mengisi file jam (frame jam/ slide) sesuai urutan nomor 1 sampai 8 dari atas ke bawah, tombol tambahan ada di bagian atas frame. 
Pendidik sebagai fasilitator dapat menampilkan konfirmasi materi jika pada saat proses diskusi mengalami kebuntuan supaya tidak terjadi miskonsepsi materi, seperti pada gambar 4 berikut ini:

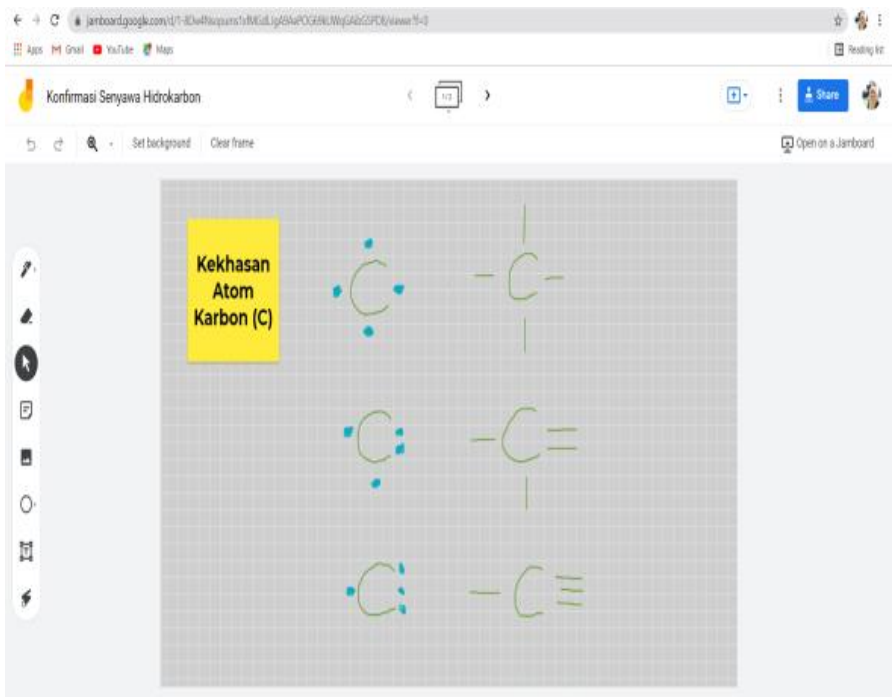

Gambar 4. Konfirmasi Jam dari pendidik.

Tahap kedua yaitu pelaksanaan Pembelajaran Jarak Jauh kimia ini merupakan gabungan pembelajaran asynchronous (melalui Whatsapp Group dan Google Classroom) dan synchronous (melalui google meet dan google jamboard). Link google meet dibagikan di google classroom kelas, sehingga saat jadwal PJJ kimia, peserta didik langsung membuka google classroom untuk mengikuti kegiatan apa yang akan dipelajari pada saat itu. Pemanfaatan google jamboard pada PJJ kimia sangat membantu proses diskusi sesama peserta didik dengan pendidik seperti di kelas nyata, yaitu dengan media google jamboard ini dapat terjadi interaksi langsung (real time) saat menuliskan hasil penemuan pemahaman peserta didik dan jika masih ada peserta didik yang kesuliatan memahami materi itu, pendidik sebagai fasilitator dapat membimbing dan mengarahkan supaya mereka dapat memahami materi tersebut. Karena meskipun dalam Pembelajaran Jarak Jauh saat ini, kegiatan pembelajaran tetap harus berbasis saintifik, yaitu dengan model pembelajaran discovery learning dan Lembar Kegiatan Peserta Didik (LKPD) yang membimbing peserta didik secara mandiri dalam menemukan pemahaman materi yang sedang dipelajarinya dengan berkolaboratif melalui diskusi. Adapun manfaat media google jamboard dalam pembelajaran kimia ini adalah sebagai media penunjang dalam berdiskusi, karena pembelajaran kimia tidak efektif jika dilakukan hanya dengan saling berkomunikasi secara lisan saja pada saat meeting, dalam pembelajaran eksakta yang memerlukan penjelasan matematis membutuhkan media google jamboard yang secara gratis disediakan oleh google. Diperlukan sarana seperti papan tulis digital untuk memvisualisasikan yang disampaikan sehingga sesama peserta didik dapat memahami apa yang sedang didiskusikan.

\section{Pembahasan}

Berdasarkan hasil penelitian ini, pelaksanaan tahap persiapan dapat berjalan lancar. Ada beberapa peserta didik yang masih bingung pengoperasian google jamboard karena masih baru kali ini menggunakannya, namun dengan bantuan tutorial temannya menjadi bisa.

Tahap kedua yaitu pelaksanaan Pembelajaran Jarak Jauh kimia ini terlaksana dengan baik, meski ada sedikit hambatan pada peserta didik yang provider kartunya (Indosat) tersendatsendat. Namun pada akhirnya dapat juga dia menampilkan layar jamboard hasil pengerjaan Lembar Kegiatan Peserta Didik. Pemanfaatan google jamboard pada PJJ kimia sangat membantu proses diskusi tahap pengolahan data LKPD antar peserta didik dengan pendidik 
seperti di kelas nyata, karena dapat terjadi interaksi langsung (real time) saat menuliskan hasil penemuan pemahaman peserta didik dan jika masih ada peserta didik yang kesuliatan memahami materi itu, pendidik sebagai fasilitator dapat membimbing dan mengarahkan supaya mereka dapat memahami materi tersebut dengan menampilkan Konfirmasai Senyawa Karbon Jam, sehingga tidak terjadi miskonsepsi materi ini yang tentunya berkaitan dengan materi berikutnya. Berikut adalah foto kegiatan Pembelajaran Jarak Jauh kimia:

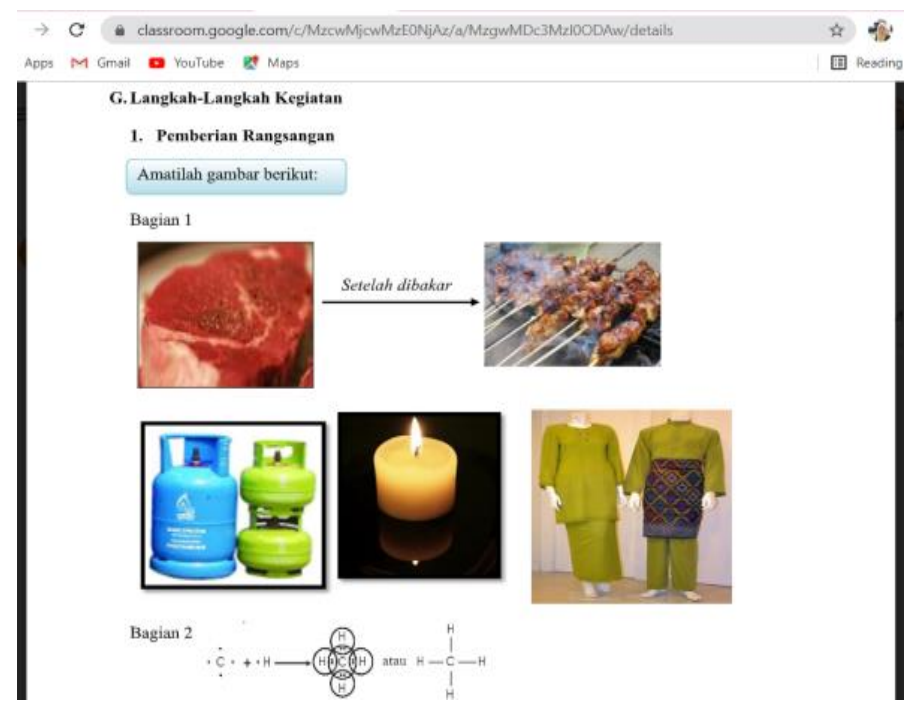

Gambar 5. Tahap pemberian rangsangan LKPD sesuai langkah pembelajaran discovery learning di google classroom.

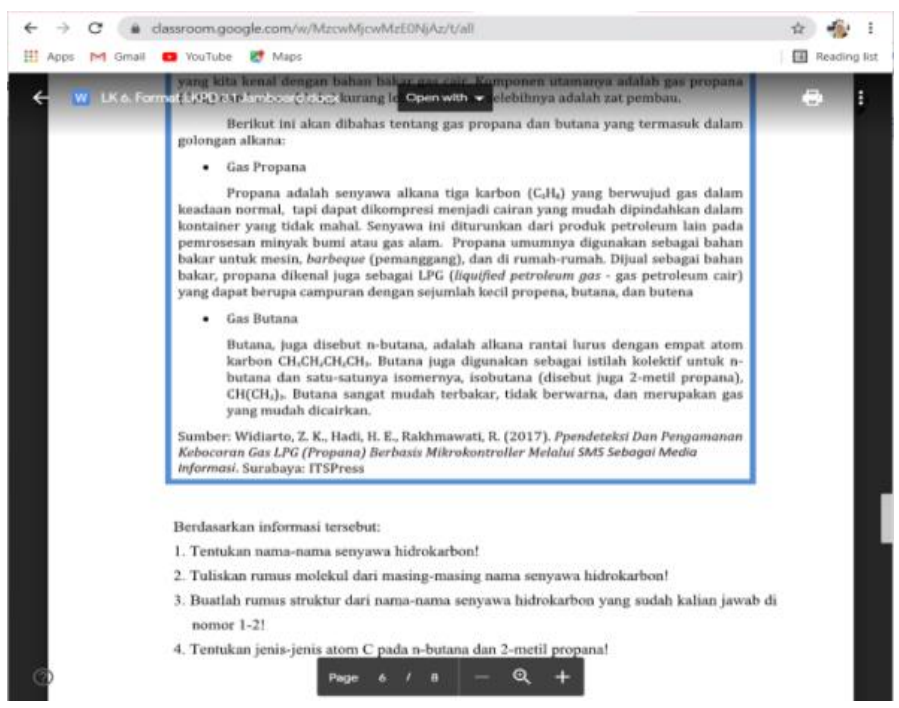

Gambar 6. Tahap pengolahan data LKPD sesuai langkah pembelajaran discovery learning di google classroom. 


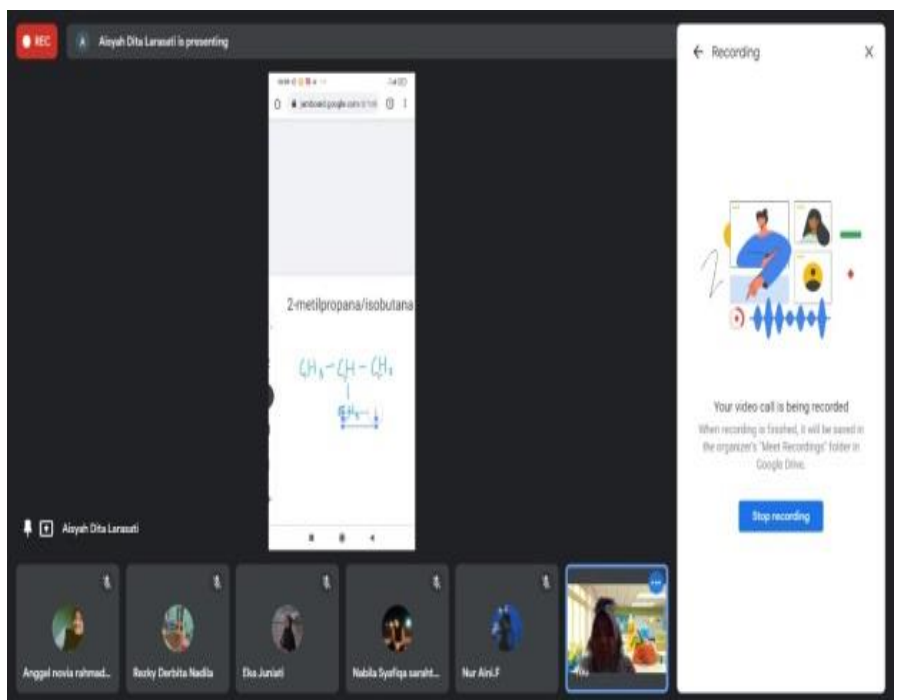

Gambar 7. Kegiatan presentasi peserta didik menggunakan google jamboard.

Ternyata dengan singkatnya waktu persiapan, peserta didik dapat mengaplikasikan google jamboard saat Pembelajaran Jarak Jauh kimia dengan baik. Kegiatan diskusi kolaboratif pada tahap pengolahan data ini memberikan ruang pada peserta didik untuk menampilkan hasil penemuan pemahaman mereka dengan percaya diri, dan siap untuk mendapatkan pertanyaan atau masukan dari peserta didik lainnya. Dibandingkan pada kegiatan diskusi sebelum menggunakan google jamboard, jumlah peserta didik yang berpartisipasi aktif pada kegiatan diskusi menunjukkan adanya peningkatan yaitu 14 menjadi 25 dari 31 keseluruhan peserta didik, disajikan pada gambar 7 berikut:

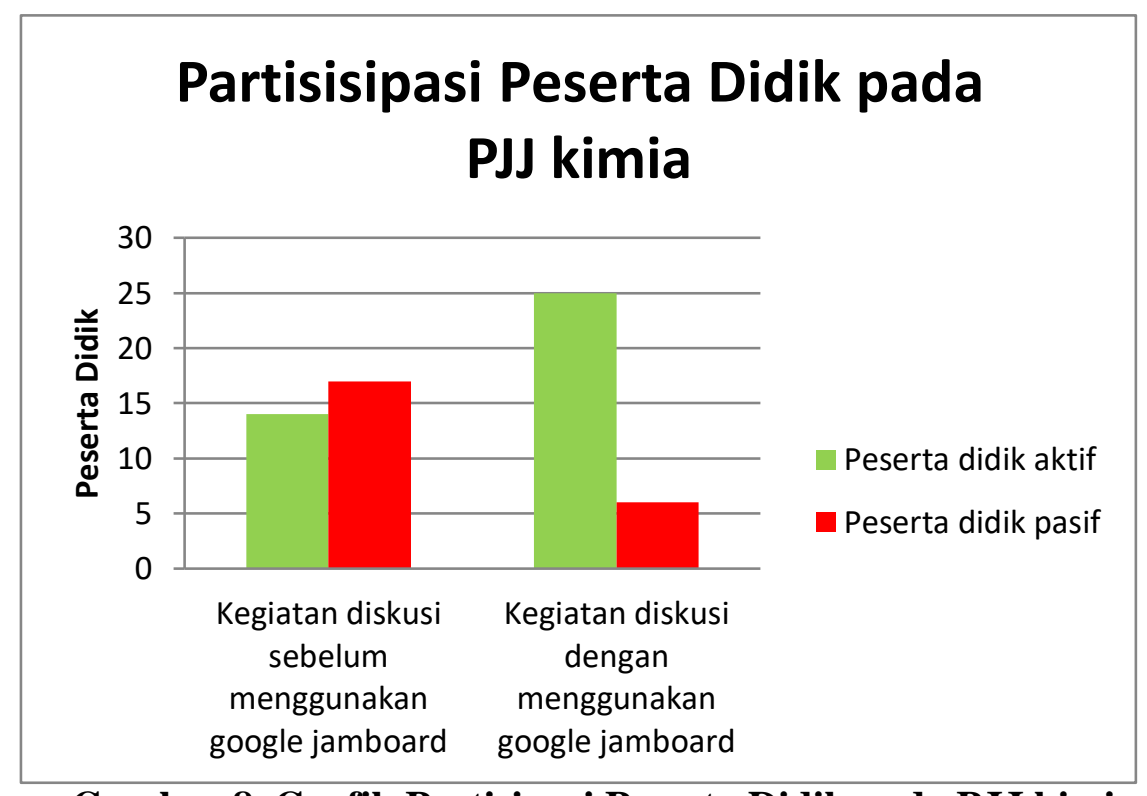

Gambar 8. Grafik Partisipasi Peserta Didik pada PJJ kimia.

Peserta didik merasa senang mengikuti pembelajaran seperti ini karena lebih jelas dalam pemberian penjelasan matematis pada penulisan rumus-rumus molekul dan rumus-rumus struktur senyawa hidrokarbon (alkana, alkena, alkuna). Penulisan rumus seperti ini tidak dapat dimengerti peserta didik jika hanya disampaikan secara lisan tanpa tulisan real time, dengan proses kegiatan Pembelajaran Jarak Jauh seperti ini membuat materi lebih mudah dimengerti. Sehingga media google jamboard dapat digunakan oleh pendidik mata pelajaran eksakta lain yang memerlukan penjelasan bersifat matematis dalam menyajikan Pembelajaran Jarak Jauh yang lebih efektif. Sesuai dengan penelitian Hasanah (2020), hasil penelitiannya menyatakan 
bahwa ada pengaruh positif penggunaan media jamboard terhadap motivasi belajar dan hasil belajar tajwid.

\section{KESIMPULAN}

Media google jamboard dapat digunakan sebagai penunjang Pembelajaran Jarak Jauh kimia pada pertemuan tatap maya google meet. Fitur google jamboard dari google ini berfungsi sebagai papan tulis digital yang sangat membantu ketika memberikan penjelasan yang bersifat matematis, karena pada mata pelajaran kimia materi senyawa hidrokarbon diperlukan dalam menuliskan rumus molekul dan rumus struktur. Penulisan dan penjelasan rumus molekul dan rumus struktur pada senyawa karbon ini tidak dapat diberikan hanya melalui bahasa lisan tanpa ada visualisasi secara langsung (real time) supaya tidak terjadi miskonsepsi materi.

Peserta didik menjadi lebih tertarik dalam mengikuti Pembelajaran Jarak Jauh kimia, karena dengan pemanfaatan media google jamboard ini mendukung model pembelajaran discovery learning dalam menyelesaikan Lembar Kegiatan Peserta Didik (LKPD) sehingga ketika mendiskusikan tahap pengolahan data LKPD, peserta didik terdorong melakukan penemuan secara kolaboratif pada saat pertemuan tatap maya. Pemanfaatan google jamboard dapat digunakan untuk materi kimia lainnya atau mata pelajaran lain yang memerlukan penjelasan bersifat matematis.

\section{DAFTAR PUSTAKA}

Gideon, S \& Rahmansyah, A. A. (2021). Implementasi Pembelajaran Sinkronus pada Mata Kuliah Fisika 1 Menggunakan Discord Dipadukan dengan Google Jamboard dan Powerpoint (Politeknik Teknologi Kimia Industri Medan, Indonesia). Physics Education Research Journal, 3(1), 1-10, from doi: https://doi.org/10.21580/perj.2021.3.1.6570

Hasanah, Eva. (2020). Pengaruh Media Jamboard Terhadap Motivasi Belajar Dan Hasil Belajar Tajwid (Studi Asosiasi Pada Siswa Kelas IX SMP Islam Al Azhar 1 Jakarta) http://repository.iiq.ac.id//handle/123456789/1040

Indah Math, 2021, 5 Maret. Cara Menggunakan Jamboard Google Untuk Pembelajaran Daring [Video]. Youtube. https://www.youtube.com/watch?v=rVAnBX5-vbw

Langit Merah, 2020, 31 Desember. Tutorial Cara Menggunakan Jamboard [Video]. Youtube. https://www.youtube.com/watch?v=wAU2_o2A6XQ

Permendikbud 2016 No. 22, Standar Proses Pendidikan Dasar dan Menengah.

Permendikbud 2018 No. 37, Kompetensi Inti dan Kompetensi Dasar Pelajaran Pada Kurikulum 2013 Pendidikan Dasar dan Menengah.

Pernantah, P. S., Nova, \& Ramadhani, A. S. (2021). Penggunaan Aplikasi Google Meet dalam Menunjang Keefektifan Belajar Daring Masa Pandemi Covid-19 di SMA Negeri 3 Pekanbaru. Jurnal Ilmu Pendidikan, 21(1), 45-50, from doi: https://doi.org/10.24036/pedagogi.v21i1.991.

Rosidah, Ati. (2021). Pemanfaatan Google Jamboard Sebagai Media Untuk Pembelajaran Interaktif Selama Pembelajaran Jarak Jauh, from https://lpmpdki.kemdikbud.go.id/pemanfaatan-google-jamboard-sebagai-media-untukpembelajaran-interaktif-selama-pembelajaran-jarak-jauh/

Sibawaih, I. \& Rahayu, A. I. (2017). Analisis Pola Asuh Orang Tua Terhadap Gaya Belajar Siswa Di Sekolah Menengah Atas Kharismawita Jakarta Selatan. Researh and Development Journal Of Educatio, 3(2),26-35, from doi: http://dx.doi.org/10.30998/rdje.v3i2.2014

Siyoto, S. \& M. Ali Sodik. (2015). Dasar Metodologi Penelitian. Sleman: Literasi Media Publishing. 